\title{
Measuring the UK's human capital stock
}

Richard Jones and Blessing Chiripanhura

Office for National Statistics

\section{Summary}

Estimates of the UK's stock of human capital are derived by applying a lifetime labour income methodology to data from the UK Labour Force Survey. The results show that using an annual discount rate of 3.5 per cent and assuming annual labour productivity growth of 2 per cent, the market value of the UK's human capital stock in 2009 was $£ 16,686$ billion. This is more than two-and-a-half times the Blue Book estimate of the Net Worth of the UK for the same year and $£ 2,703$ billion higher than the estimate for the human capital stock in 2001. In 2009, the average human capital stock per head of working age population was $£ 419,326$. This is $£ 46,797$ higher than in 2001 but only $£ 717$ higher than in 2007 . Less time in paid employment over their lifetime and lower average labour market earnings means that the total market value of women's human capital ( $£ 6,481$ billion) was around 63 per cent of men's ( $£ 10,206$ billion). In 2009, one-third of the human capital stock was embodied in the $\mathbf{2 1 . 7}$ per cent of the working age population whose highest educational attainment was a degree or equivalent.

\section{Introduction}

This paper contributes to a number of key agendas by presenting experimental measures of the UK's stock of human capital. These estimates are relevant to:

- the explanation of productivity performance, since human capital is a key factor of production;

- to the fiscal policy debate, since a crucial question is the extent to which productive capital was impaired by the financial crisis and recession, and thus the productive potential of the UK economy; and

- to the measurement of national well-being, since the evidence suggests a clear relationship between human capital formation and people's perceived well-being.

For over three centuries economists have been interested in valuing the productive capacity of the workers in an economy. ${ }^{1}$ Despite advances in accounting systems, present day National Accounts are still considered by some to be limited in their analysis of human capital. Recognising this, the Atkinson Review (Atkinson, 2005) and the Commission on the Measurement of Economic Performance and Social Progress (CMEPSP, 2009) recommended the development of measures of the stock of human capital. There is international acceptance of the need to improve measures of human capital and ONS is a member of an international consortium developing such measures. ${ }^{2}$ 
This paper presents experimental estimates of the UK's human capital stock. The paper first discusses the concept of human capital and its importance. Next, it considers the alternative methods for measuring human capital before explaining in detail the lifetime labour income approach. The methodology is then applied to data from the Labour Force Survey to produce estimates of the UK human's capital stock between 2001 and 2009 inclusive. These results and the factors driving them are then discussed. The paper ends with conclusions and suggestions for further work.

\section{What is human capital?}

OECD (2001a: 18) define human capital as 'the knowledge, skills, competencies and attributes embodied in individuals that facilitate the creation of personal, social and economic well-being.' This is a broad definition, encompassing a range of attributes (such as knowledge, skills, competencies and health conditions) of individuals. For the purposes of this paper, the term human capital is restricted to people's knowledge, skills and competencies, which means excluding other attributes such as the heath of the population. Thus, any activity that adds to these can be thought of as investment in human capital. These activities can take place throughout an individual's life and in a range of environments. OECD (2001) identifies four main contexts for human capital development:

\section{Learning within family and early childcare settings}

Families contribute to the development of human capital in their children through direct expenditures on educational materials etc and through time spent fostering learning habits and attitudes.

\section{Formal education and training}

This includes activities ranging from early childhood education, school-based compulsory education, post-compulsory vocational or general education, tertiary education, public labour market education, adult education and so on.

\section{Workplace training}

Firms and organisations invest in human capital to develop those skills and competencies with economic value.

\section{Informal learning}

This is a wider concept taking place through 'on-the-job' learning, in daily living and through civic participation.

For consistency with other members of the international consortium, this paper focuses on human capital acquired through participation in the formal education system, thus excluding the human capital gained in the years before primary education and in adult life. The analysis is also restricted to individual human capital rather than collective human capital. Collective human capital encompasses work organisation, work processes, information networks and other forms of intangible, non-visible knowledge which is embedded in a group of people rather than in individuals. 


\section{Why is human capital important?}

\section{Macroeconomic effects}

Human capital is recognised as having important economic impacts. At a macroeconomic level, the accumulation of human capital has been theorised as being an important driver of output growth (Solow, 1988; Romer, 1989, 1994a and 1994b). However, difficulties in controlling for other influences on growth, establishing the direction of causation ${ }^{3}$ and data limitations meant that the link between human capital and growth was not always fully supported by empirical work, for example Barro and Lee $(1993,1996)$. More recent work, however, using better data and more sophisticated analytical techniques, is more supportive of the growth and human capital relationship (Barro and Sala-i-Martin, 2004; Durlauf et al, 2005). Thus, to the extent that relationship holds, those countries with higher levels of human capital have greater potential for future growth, other things being equal.

\section{Microeconomic effects}

At the microeconomic level, individuals' labour market outcomes are linked to their human capital. The economics literature contains hundreds of studies showing positive associations between human capital (in particular educational attainment) and labour market outcomes such as employment and earnings (see Card, 1999, Psacharopoulos and Patrinos, 2004 for reviews). There is, however, some disagreement over the reason(s) for these associations. The obvious explanation is that education directly increases the productivity of individuals. Early empirical studies by Denison (1962), Kendrick (1976), Jorgenson and Griliches (1967) and others found that human capital has a positive impact on productivity. An alternative explanation may be that those people who acquire more education are more able and/or more motivated than those who do not, and earn more because of this. Closely related to this is the idea that educational attainments perform a signalling function by identifying more productive workers rather than directly raising productivity. The idea is that more able individuals find it less costly, in terms of time and effort, to acquire higher levels of education. Thus, the acquisition of qualifications indicates ability and motivation rather than directly increasing productivity (Spence, 1973 and Weiss, 1996).

\section{Inequality and human capital}

During the 1980s, the demand for less-skilled workers in developed countries fell sharply. Bartel and Lichtenberg (1987) argued that technological innovation alters demand in favour of better educated workers because they have a comparative advantage in implementing new technologies. This has led to a relative fall in the real wages of low-skilled workers. This in turn contributed to the widening of the income distribution in many industrialized nations including the UK and the US (Berman et al, 1998). Part of the observed pay gap between men and women is related to the acquisition of human capital. Mincer and Polachek (1974) suggested that, on average, women have a weaker attachment to the labour market than men and therefore have less incentive to acquire human capital, other things being equal. 
Inequality might also persist over time as educational attainments are highly correlated between generations in families (Gang and Zimmerman, 2000; Francesconi et al, 2005) and parental educational attainment has an impact on their children's future outcomes. Greenwood (1997) and Maynard and McGrath (1997) summarise the literature on these effects. They report that higher parental education is associated with lower incidence of teenage childbearing; lower levels of child abuse and neglect; better performance in school and in the labour market by the children; lower criminal propensities in children; and better health. These impacts are significant even after controlling for parental income.

\section{Externalities}

Investment in human capital may also generate externalities. These are outcomes that are due to the investment decision of some individuals but affect people who did not invest in education and for which no compensation is paid. ${ }^{4}$ Several examples have been suggested in the literature. Lucas (1988) and Jovanovic and Rob (1989) consider technological externalities, where the free movement of workers between firms within the same industry sectors and similar production technologies facilitates the transfer of knowledge and ideas. Acemoglu (1996) presents a model in which imperfect information in the employer-employee matching process generates an externality. ${ }^{5}$ Higher earnings may understate the value of acquiring human capital since jobs which require more schooling are likely to be more desirable on both monetary and non-monetary grounds (Rosen, 1985).

\section{Social effects}

Evidence on many of the social effects of human capital and in particular education is reviewed in more detail by Behrman and Stacey (1997) and Haveman and Wolfe (1984). Human capital has been related to improved health outcomes (for example Taubman and Rosen, 1982 and Grossman and Kaestner 1996); lower crime rates (Grogger, 1998 and Lochner and Moretti, 2004); measures of social capital, trust and social participation (Helliwell and Putman, 1999; Milligan et al, 2003 and Schuller et al, 2001).

\section{Diminishing returns}

The literature presented so far suggests that greater expenditure on human capital brings important benefits. It is important to note, however, that there may be diminishing returns to spending on education for higher levels of economic development (Hanushek and Kim, 1995). The rapid growth in educational attainment and levels of literacy in the past decade suggests that human capital is not in short supply in OECD countries. Moreover, a number of economists have suggested that there may be some 'over-education' taking place in Europe and the United States (see Sloane, 2003 for a review of the literature). 


\section{The accounting treatment of human capital}

Capital theory is one of the most difficult and contentious topics in economic theory and accordingly the measurement of capital is one of the most complex dimensions in the official National Accounting system. ${ }^{6}$ It has taken many years for statisticians to develop and establish the existing physical capital measurement system as it is within the System of National Accounts (SNA) 1993. Even so, there is still disagreement on several important issues.

One such debate concerns the accounting treatment of human capital, in particular whether expenditure on goods and services such as education and training should be treated as consumption or investment expenditure. ${ }^{7}$ This question stems from the observation that, similar to investment in other assets, individuals devote resources to their education incurring direct costs such as tuition fees, books etc and the indirect cost of the earnings foregone whilst studying in the hope of gaining a return on this investment in the form of higher earnings (Shultz, 1960, 1969 and 1971; Becker, 1961 and 1975). Similarly, governments invest significant resources in the education system in the anticipation of securing benefits to society.

The European System of Accounts (ESA95) defined economic assets as, 'entities functioning as a store of value over which ownership rights are enforced by institutional units, individually or collectively and from which economic benefits may be derived by their owners by holding them or using them over a period of time.' (Eurostat, 1995: para: 7.10)

OECD (1996) sets out four conditions that must be met by a resource for it to be treated as an asset of an entity for accounting purposes:

- it must be an economic resource;

- the resource must be controlled by the entity;

- the cost at the time of acquisition must be objectively measurable; and

- in day-to-day transactions, capital and labour markets place value on the output potential of the asset.

SNA 1993 acknowledged that investment in human capital investment exhibits many of the characteristics of a fixed asset in that 'it raises the productive potential of the individuals concerned and is a source of future economic benefit to them.' SNA93 and ESA95, however, exclude human capital from the asset boundary arguing that human capital is:

- non-physical;

- non-appropriable - SNA93 purports that expenditure on human capital investments should not be treated as fixed assets because, 'they are embodied in the individuals as persons' and 'cannot be transferred to others and cannot be shown in the balance sheets of the enterprises in which the individuals work';

- immeasurable; and

- incompatible with the conventions and institutions that guide the day-to-day transactions recorded by financial accounting and reporting.

Appelbaum and Hood (1993) argued that non-appropriability need not necessarily be a problem since if equipment can be measured by its original cost, human capital should also be measured 
by its original cost. In the event that an employee leaves the organization, the remaining unamortized cost can be written off. For examples, professional sports teams' players are traded and thus human capital can have the exchangeability characteristic.

Several authors have countered the SNA's argument that the human capital is immeasurable and have proposed several methods for doing so. These methods and the issues involved are discussed in the next section.

\section{Measuring human capital}

Three general approaches to measuring the human capital stock can be identified:

- measures based on educational attainment

- measures based on the value of the inputs that enter the production of human capital (input or cost-based approach)

- output (typically measured by labour market income) that stems from human capital (output or income based approach)

\section{The educational attainment based approach}

The educational attainment approach estimates human capital based on educational output indicators. This method is based on the assumption that these indicators are closely related to investment in education and this is a key element in human capital formation. Human capital encompasses more dimensions but education is arguably the most important component. A variation of this approach is to test individuals directly to determine whether they have certain attributes relevant to economic activity. Several measures have been used in the literature. For example, adult literacy rates (Romer, 1989 and Azariadis and Drazen, 1990); school enrolment rates (Barro 1991, Mankiw et al. 1992, Levine and Renelt, 1992 and Gemmell, 1996); and average years of schooling. The main limitation of these approaches is that they miss most of the elements that extend beyond that elementary level, such as numeracy, logical and analytical reasoning and scientific and technological knowledge. Thus, they are unlikely to be good proxies for human capital in developed countries (Judson, 2002). Establishing the direction of causality may be difficult since high enrolment may result from high productivity growth, rather than vice versa (Wolff, 2000).

Psacharopoulos and Arriagada (1986 and 1992) and Barro and Lee (1996) used a measure that has several advantages over literacy rates and school enrolment rates. First, it is a valid stock measure. Second, it quantifies the accumulated educational investment in the current labour force. Wachtel (1997) showed that under particular assumptions, the number of schooling years is equivalent to cost-based measures of human capital. The studies that have attempted to develop data series on years of schooling can be divided into three groups based on the method they employ: the census/survey-based estimation method (for example Psacharopoulos and Arriagada, 1986 and 1992), the projection method (for example Kyriacou, 1991); and the perpetual inventory method (Lau et al, 1991). 
This proxy has a number of short-comings. First, the years of schooling measure fails to allow for the costs and returns of education varying at different levels. Thus, this measure incorrectly assumes that one year of schooling always raises human capital by an equal amount. For example, a worker with ten years of schooling is assumed to have ten times as much human capital as a worker with one year of schooling. This assumption is at odds with the empirical literature which has typically documented diminishing returns to education (Psacharopoulos, 1994). Second, no allowance is made for differences in quality of education across time and location. Behrman and Birdsall (1983) found that neglecting quality of schooling biased estimates of returns to schooling. Since the quality of schooling varies more considerably across countries than within one country, overlooking quality is likely to create more severe biases. Third, this measure unrealistically assumes that workers of different education categories are perfect substitutes for each other as long as their years of schooling are equal.

Thus, while informative for a number of purposes, these indicators are less suitable for other uses such as the assessment of the 'sustainability' of a development path, which require comparing changes in the aggregate stock of human capital with those in the stocks of other types of assets. Such comparisons typically require a common monetary metric.

\section{Cost of production method}

Using the cost of production method the value of the human capital stock is calculated as being the depreciated value of the monetary amount spent on investment in human capital. Kendrick (1976) and Eisner (1985 and1989) provide seminal examples of this approach. One advantage of this approach is that it provides an estimate of the resources invested in the education and other human capital related sectors, which can be useful for cost-benefit analyses.

This approach has several limitations. The first is that it is only supply-side based, yet the value of human capital is also determined by the demand for it. This makes cross-sectional and intertemporal comparisons difficult. This method also fails to take account of the heterogeneity of individuals. As an illustration, consider two children, one of whom is innately less able than the other. To the extent that it more expensive to educate the less able child to a particular attainment level the cost-based approach will overestimate that child's human capital while underestimating the human capital of the more able child. Similarly, differences in the quality of education providers are ignored in this method. For example, schools vary in their quality as do the teachers within schools. Hanushek (2000) and Lavy (2002) found that after social background, the quality of teaching is the best predictor of how well students do in school.

Another difficulty of this approach is identifying which costs should be included and how they should be measured. Simply reclassifying all human capital expenditures as investment rather than consumption may not be correct. To the extent that individuals enjoy their courses or have their range of interests, tastes and activities extended, educational expenditures also provide some consumption benefits. Thus, the difficulty lies in determining which part of educational expenditure is investment spending and which part is consumption (see Schultz, 1961 and Shaffer, 1961 for a discussion). Part of the expenditure on schooling could also be regarded as a form of childcare in that it provides children with a safe environment allowing their parents to use their time in other ways. Similarly, Kendrick (1976) classified the costs of raising children to the age of fourteen as 
human capital investments, reasoning that these expenses, typically on necessities such as food and clothing, compete with other types of investment. This contradicts Bowman (1962) and Machlup (1984) who argued with this view, maintaining that basic expenditures should be considered as consumption.

Calculating the depreciation rate is an important element of this method. Like physical capital, human capital depreciates over time, because of:

- the wear of skills due to aging, or illness;

- the atrophy of skills due to insufficient use;

- job-specific obsolescence due to technological and organizational change;

- sector-specific obsolescence due to shifts in employment; and

- firm-specific skills obsolescence due to displacement (Grip and Van Loo, 2002).

Grip and Van Loo also suggested ways in which the obsolescence of human capital could be measured as:

- objective methods such as testing;

- subjective method, for example asking workers or their employers;

- workers' wages; and

- the probability of losing employment.

All four measures have limitations. The last two indirect methods have the advantage that they measure the labour market effects of skills obsolescence that are the main concern on human capital obsolescence in a knowledge economy: a lower productivity and lower labour market participation.

The two main methods used to calculate depreciation in the literature are: the straight-line method (Eisner, 1988) in which a constant proportion of the original human capital is assumed to become obsolete in each period and the (modified) double declining balance method (Kendrick, 1976), in which depreciation is assumed to be higher in the early years of an assets life. The rationale behind this method is that physical capital depreciates faster in early years of life, so using the double declining balance method provides consistency across different types of capital. The appreciation of human capital is often ignored in the literature, despite some empirical evidence that showed that human capital can appreciate at younger ages (Mincer, 1958, 1974; Graham and Webb, 1979).

Some aspects of education aim to create 'skills for life', for example educational attainment that enables individuals to enjoy leisure activities during and after their working life and these skills may appreciate or depreciate depending on use and wider factors.

\section{The output or income based approach}

The output or income based approach measures human capital by summing the discounted values of all future income streams that all individuals in the population expect to earn throughout their lifetime (Farr, 1853; Jorgenson and Fraumeni, 1989, 1992a,b). This method is 'forward-looking' 
because it focuses on expected returns to investment, as opposed to the 'backward-looking' method whose focus is on the historical costs of production.

One advantage of this approach is that there is no need to assume an arbitrary rate of depreciation since it is already implicitly captured. The main limitation of this approach is that it relies on the assumption that labour is paid according to its marginal productivity. In practice, factors such as market power, trade unions, discrimination and so on all affect wages. This measure is also sensitive to the choice of discount rate and the retirement age. This method relies upon accurate data on earnings, life tables and employment rates.

A variation of the income-based approach is presented by Mulligan and Sala-i-Martin (2000) who calculated an index measure of human capital. Specifically, they measure human capital as the total labour income per capita divided by the wage of the uneducated. The rationale for this method is that labour income incorporates not only the workers' human capital but also the physical capital available to them, such that for a given level of human capital workers in regions with higher physical capital will tend to earn higher wages. Therefore, to obtain a 'pure' measure of human capital, the effect of physical capital should be netted out. This method assumes that uneducated workers always have the same human capital, although they do not necessarily earn the same income.

A drawback which is common to all these approaches is that, as noted before, formal education and training are not the only determinants of human capital. Some of an individual's capital is innate to them and is in some sense, a non-produced asset. Thus, the asset created by education could be regarded as improvements in human capital by education and training. Another drawback of these measures is that they focus on individual's human capital and aggregate them to arrive at the population measure. This ignores spillovers between workers so that the whole may be more than the sum of the parts.

This paper applies the output or income based measure to value human capital in the UK. This method is preferred to a cost of input approach or a quality adjusted student count approach to measuring the output of education for several reasons. First, it allows output to be measured independently of inputs. Accordingly, the productivity of the education sector can be estimated. Students and the time they spent on education are inputs to the education process, not outputs. Second, it is difficult to quantify elements of the education process that produce higher output. Accordingly, it makes sense to use labour market evaluations as representing the worth of an educated individual. Quality-adjustments applied to student counts are typically very small and perhaps not fully representative of the difference between students (the inputs) and educated individuals (the output). Finally, the Atkinson Report (2005, para. 9.33-9.34) recommends exploring a lifetime income (human capital) approach such as that implemented by Jorgenson and Fraumeni.

\section{Comparison with the measurement of the physical capital stock}

The estimation method used for measuring human capital is quite different from that conventionally used for physical capital where in the latter the directly available information covers the quantity of new capital goods added to the existing capital stock. The magnitude of the stock is indirectly derived using the perpetual inventory method. As the owners and users of capital goods are often 
one and the same, the quantity of capital services has to be imputed indirectly as well. For human capital, it is the value of labour services that is directly observable (from labour market transactions), and the stock of human capital can be directly estimated from the present value of discounted lifetime labour income streams. Because the changes in the human capital stock between the beginning and the end of an accounting period must equal the sum of human capital flows, the amount of investment in human capital is indirectly derived by decomposing the stock changes into various components.

\section{Methodology}

This section sets out how the output or income based approach is implemented. The methodology is described in two parts. The first part describes how the dataset is constructed and presents some of the descriptive statistics. The second shows how the dataset is used to derive estimates of the human capital stock. To illustrate the method the construction of estimates for quarter four of 2009 are presented in detail.

\section{Stage one: Construction of the database}

The first stage is the construction of a database containing the economic value of labour market activities for various categories of people. This database contains information on the number of people, their earnings (when employed), enrolment rates for different levels of education, employment rates, and survival rates. All these data should, ideally, be cross-classified by gender, age and levels of educational attainment but this was not possible in all cases. For example, in practice, most data on survival rates do not distinguish between different categories of educational attainment (that is, survival rates differ only according to the age and gender of each person).

The main source of data used in the analysis is the Labour Force Survey (LFS). ${ }^{8}$ Conducted by the Office for National Statistics, this is a quarterly sample survey of households living at private addresses in Great Britain. Its purpose is to provide information on the UK labour market that can then be used to develop, manage, evaluate and report on labour market policies. The survey seeks information on respondents' personal circumstances and their labour market status during a specific reference period, normally a period of one week or four weeks (depending on the topic) immediately prior to the interview. The survey collects household and individual data from a nationally representative sample. ${ }^{9}$ The LFS was chosen ahead of other data sources because it contains relevant demographic and labour market information. The survey is also on-going and has a collection of previous waves allowing the construction of a time-series of estimates.

This paper focuses on the LFS data covering the years 2001 to 2009 inclusive. The human capital series cannot be calculated consistently for years prior to 2001 because of changes in the questions asked about pay in the Labour Force Survey. This survey covers over 120,000 individuals in over 50,000 households distributed across the UK. In common with other studies, this paper focuses on effective human capital (that is, human capital of people of working age) as this is more relevant for growth and for comparative purposes than estimates that cover the whole population. Thus, the paper focuses on individuals aged between 16 and 64 years, as these limits 
mark the end of compulsory education and the current retirement age. ${ }^{10}$ This is the convention that has been adopted by members of the international consortium developing measures of human capital and is a somewhat arbitrary choice that, while not crucial, could easily be relaxed and extended to other age groups.

The human capital of those people not in employment is valued at zero. This is consistent with the OECD's guidance on the measurement of physical capital which states that, 'be counted as part of the capital stock all that is required is that assets are present at production sites and capable of being used in production or that they are available for renting by their owners to producers.'

(OECD, 2001b: 31).

Reponses to the Labour Force Survey question on highest educational attainment are classified into 49 categories. ${ }^{11}$ To make the analysis practicable, these results are compressed into 7 wider categories: ${ }^{12}$

- degree or equivalent

- higher education

- GCE A level or equivalent

- GCSE grades A-C or equivalent

- other qualifications

- no qualification

- don't know

The survival rate is the conditional probability that a person who is alive in year $t$ will also be living in year $t+1$. Information on survival rates, by gender and individual year of age, was derived from country life-tables published in ONS' interim life tables.

\section{Stage two: Using the dataset}

In the second stage the dataset is used to produce estimates of the human capital stock. Under competitive market conditions, the market price of an asset is related to the rental income that the asset is expected to earn through the following equation (the scrap value is ignored).

\section{Equation 1}

$$
V_{t}=\sum_{\tau=1}^{T} \frac{f_{t+\tau-1}}{(1+r)^{\tau}}
$$

where

$V_{t}$ is the real market value of an asset at the beginning of year $t$

$f$ is the real rental income earned in each period

$T$ is the service life of the asset in years

$\tau$ takes values of $1,2,3 \ldots . \mathrm{T}$, and

$r$ is the discount rate 
The corresponding equation for a labour asset involves using total labour market earnings as the rental income and working life as the service. Thus the real market value of an asset at the beginning of year $t$, is the present value of lifetime labour income.

Lifetime labour income is calculated for a representative individual in each classified category (by gender, age and educational attainment) in the database. A key assumption used here is that an individual of a given age, gender and educational level will, in year $t+1$, have the same labour income and other characteristics (for example school enrolment rate, employment rate, survival rate, and so on) as those of a person who, in year $t$, is one year older but has otherwise the same characteristics (for example gender and educational level).

Based on this assumption, the lifetime labour income of an individual was computed as follows:

- for individuals aged 65 and over (the 'retirement' stage), their lifetime labour income is zero since, by assumption, these persons will not receive earnings after withdrawing from the labour market

- for persons aged 16 to 64 (the 'study-and-work' stage), their lifetime labour income (LLI) is estimated as

\section{Equation 2}

$$
\begin{aligned}
& \operatorname{LLI}_{\text {age }}^{\text {edu }}=\mathrm{EMR}_{\text {age }}^{\text {edu }} \mathrm{ALI}_{\text {age }}^{\text {edu }}+\left\{1-\sum_{\text {edu }} \mathrm{ENR}_{\text {age }}^{\text {edu-edu }}\right\} \mathrm{SUR}_{\text {age }+1} \operatorname{LLI}_{\text {age+ } 1}^{\text {edu }}\{(1+\mathrm{r}) /(1+\delta)\} \\
& +\sum_{\text {edu }} \operatorname{ENR}_{\text {age }}^{\text {edu-edu }}\left\{\left(\sum_{\mathrm{t}=1}^{\mathrm{t}_{\text {edu-cdu }}} \mathrm{SUR}_{\text {age }+1} \mathrm{LLI}_{\text {age }+1}^{\overline{\text { edu }}}\{(1+\mathrm{r}) /(1+\delta)\}^{\mathrm{t}}\right) / \mathrm{t}_{\text {edu- } \overline{\text { edu }}}\right\}
\end{aligned}
$$

where

$\mathrm{LLI}_{\mathrm{age}}^{\mathrm{edu}}$ is the present value of lifetime labour income for a representative individual with educational level of edu at age of age;

$E N R_{\text {age }}^{\text {edu-edu }}$ is the educational enrolment rate for a representative individual with educational level of edu pursuing his/her studies into a higher educational level of $\overline{e d u}$;

$E M R_{\text {age }}^{\text {edu-edu }}$ is the employment rate for a representative individual with educational level of edu at age of age;

$\mathrm{ALI}_{\text {age }}^{\mathrm{edu}}$ is the current total annual labour income for a representative individual with educational level of edu at age of age;

$\mathrm{SUR}_{\text {age }+1}$ is the survival rate (i.e. the probability of surviving one more year) at age of "age". 
$t_{\text {edu-edu }}$ is the school duration for this individual with educational level of edu to complete a higher educational level of $\overline{e d u}$;

$r$ is the rate of growth in real wages. Lindsay (2004) estimates that the long run UK labour productivity growth is around two per cent per annum; and

$\delta$ is the discount rate. HM Treasury's Green Book (2003), which provides guidelines for appraisal and evaluation in central government recommends using a discount rate of 3.5 per cent per annum.

At the start of each period, the representative individual in the next year can either continue his/her work (holding the same educational level as before) and earn income of $\mathrm{SUR}_{\text {age }+1} \operatorname{LLI}_{\text {age+1 }}^{\text {edu }}\{(1+\mathrm{r}) /(1+\delta)\}$ with the probability of $\left\{1-\sum_{\text {edu }} E N R_{\text {age }}^{\text {edu-edu }}\right\}$ or undertake some education and (after completing study having gained a higher educational level) receive income of

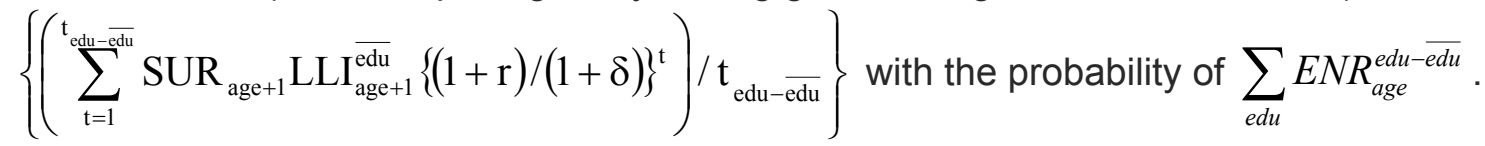

Therefore, his/her lifetime income in the next year is the expected value of the outcomes of these two courses of action.

The empirical implementation of Equation 2 is based on backwards recursion. In this approach, the lifetime labour income of a person aged 64 (that is one year before retirement) is simply his/her current labour income because his/her lifetime labour income at 65 is zero by construction. Similarly, the lifetime labour income of a person aged 63 is equal to his current labour income plus the present value of the lifetime labour income of a person aged 64, and so forth.

In estimating lifetime labour income by using Equation 2 several practical assumptions are made, some of which are used as well by other studies in the field (for example Gu and Wong, 2008; Le et al, 2006; Liu and Greaker, 2009; Wei, 2004, 2007). The most important assumptions are as follows:

- individuals can only enrol in a higher educational level than the one they have already completed;

- no further enrolment is allowed for people having already achieved the highest educational level;

- students enrolled in educational institutions requiring more than one year to complete are assumed to be evenly distributed across the total study-period. This is equivalent to saying that, during each school-year, there is the same (equal) proportion of the total students that will complete the study; and

- no delaying and quitting are allowed during the whole study period. 
The lifetime labour income measures estimated through Equation 2 are applied to all individuals in each age/educational categories to compute the human capital stock for each category. Summing up the stocks of human capital across all classified categories yields the estimate of the aggregate value of the human capital stock $(H C)$.

\section{Equation 3}

$$
H C=\sum_{\text {age edu }} \sum_{\text {ed }} L L I_{\text {age }}^{\text {edu }} N_{\text {age }}^{\text {edu }}
$$

where $N_{a g e}^{e d u}$ is the number of individuals in the corresponding age/educational category. Equation 3 can be applied separately to both males and females to estimate the stock of human capital by gender.

\section{Results}

Applying the methodology described in the previous section and using an annual discount rate of 3.5 per cent and a labour productivity growth rate of 2 per cent per annum, the UK's human capital stock is estimated to have been worth $£ 16,686$ billion in 2009 . Dividing this amongst the working age population gives an average of around $£ 419,326$ per individual.

The reasonableness of the estimates can be illustrated using the following calculation that for simplicity ignores discounting, real wage growth and so on. The number of employed individuals in the economy was around 28 million, multiplying this by average annual earnings of around $£ 25,000$ and an average working life remaining of 24.5 years ${ }^{13}$ gives 17,150 billion. $^{14}$

\section{Sensitivity analysis}

Table 1 shows how these estimates change when the discount rate and labour productivity growth rate change. Increasing the assumed labour productivity growth rate by one percentage point whilst holding everything else constant increases the estimate of the human capital stock by around $£ 2,506$ billion. Conversely, lowering the assumed labour productivity growth rate by one percentage point decreases the estimate of the human capital stock by $£ 2,044$ billion. A similar exercise, this time changing the discount rate by one percentage point, leads to changes of a similar magnitude but in the opposite direction in the estimates of the human capital stock.

As noted in the previous section, restricting the sample to individuals aged between 16 and 64 years is a somewhat arbitrary assumption particularly at the higher end of the age range. Table 2 illustrates the effects of changes in the upper age bound on estimates of the human capital with a discount rate of 3.5 per cent and a labour productivity growth rate of 2 per cent. As would be expected, increasing the upper age bound increases the estimates of the human capital stock since the human capital of additional workers is included in the estimate and the expected working 
lives of individuals already in the sample is extended, raising the value of their human capital. The increases become smaller as the upper age bound is increased because the employment rate and total income is lower in each age-year cohort added to the sample.

\section{Table $1 \quad$ Estimates of the UK's human capital stock, 2009}

\begin{tabular}{cccc}
\hline $\begin{array}{c}\text { Discount rate } \\
\text { (per cent) }\end{array}$ & $\begin{array}{c}\text { Labour productivity } \\
\text { growth rate } \\
\text { (per cent) }\end{array}$ & $\begin{array}{c}\text { Totals } \\
\text { (£ billion) }\end{array}$ & $\begin{array}{c}\text { Per head of working } \\
\text { age population } \\
\text { (£'000s) }\end{array}$ \\
\hline 3.50 & 2.00 & 16,686 & 419 \\
3.50 & 3.00 & 19,192 & 483 \\
3.50 & 1.00 & 14,642 & 368 \\
2.50 & 2.00 & 19,178 & 482 \\
4.50 & 2.00 & 14,686 & 369 \\
\hline
\end{tabular}

Source: Office for National Statistics

Table 2 Estimates of the UK's human capital stock in 2009 for different upper age limits

\begin{tabular}{cc}
\hline Upper Age Limit & $\begin{array}{c}\text { Totals } \\
(£ \text { billion })\end{array}$ \\
\hline 64 & 16,686 \\
65 & 16,993 \\
66 & 17,272 \\
67 & 17,530 \\
68 & 17,758 \\
69 & 17,943 \\
70 & 18,083 \\
\hline
\end{tabular}

Source: Office for National Statistics

\section{The distribution of human capital}

Table 3 shows the distribution of human capital across gender, age groups and educational attainments in 2009. The figures show that the estimated total market value of women's human capital was around 63 per cent of men's human capital. On average, a working-age man had around $£ 516,000$ worth of human capital compared to the average of around $£ 324,000$ for a working-age woman. This distribution was mainly the result of men earning more and having higher employment rates than women on average. Table 3 also shows that the stock of human capital was disproportionately concentrated in younger workers. For example, just over one-infive of the working age population were aged between 20 and 29 inclusive but this group embodied 
one-third of the human capital stock, showing that being relatively young and having more years of paid employment remaining more than offset the effect of having higher earnings whilst being relatively old. As might be expected, the value of the human capital stock was disproportionately embodied in those workers with the highest educational attainments: 33 per cent of the UK's human was embodied in the 22 per cent of the working age population with the highest qualification level. In contrast, only six per cent was embodied in the 11 per cent of the working age population with no qualifications.

\section{Table 3 Distribution of the UK's human capital stock in 2009}

\begin{tabular}{|c|c|c|c|}
\hline & $\begin{array}{l}\text { Share of working age } \\
\text { population } \\
\text { (per cent) }\end{array}$ & $\begin{array}{l}\text { Share of total human capital } \\
\text { stock } \\
\text { (per cent) }\end{array}$ & $\begin{array}{c}\text { Human capital (£ } \\
\text { billion) }\end{array}$ \\
\hline \multicolumn{4}{|l|}{ Gender } \\
\hline Male & 49.8 & 61.2 & $10,205.6$ \\
\hline Female & 50.2 & 38.8 & $6,480.9$ \\
\hline \multicolumn{4}{|l|}{ Age band } \\
\hline $16-19$ & 7.9 & 10.2 & $1,696.7$ \\
\hline $20-24$ & 10.6 & 16.1 & $2,680.9$ \\
\hline $25-29$ & 10.5 & 16.3 & $2,714.6$ \\
\hline $30-34$ & 9.6 & 13.8 & $2,307.6$ \\
\hline $35-39$ & 10.7 & 13.3 & $2,224.4$ \\
\hline $40-44$ & 11.6 & 11.8 & $1,965.1$ \\
\hline $45-49$ & 11.2 & 9.0 & $1,493.4$ \\
\hline $50-54$ & 9.8 & 5.5 & 924.6 \\
\hline $55-59$ & 8.9 & 3.0 & 501.9 \\
\hline $60-64$ & 9.3 & 1.1 & 176.2 \\
\hline \multicolumn{4}{|l|}{ Highest educational attainment } \\
\hline Degree or equivalent & 21.7 & 33.7 & $5,615.4$ \\
\hline Higher education & 8.8 & 8.6 & $1,431.3$ \\
\hline GCE A level or equivalent & 22.7 & 22.3 & $3,720.4$ \\
\hline GCSE grades $\mathrm{A}-\mathrm{C}$ or equivalent & 22.4 & 19.6 & $3,263.8$ \\
\hline Other qualifications & 13.4 & 9.8 & $1,634.7$ \\
\hline No qualification & 11.0 & 6.1 & $1,019.9$ \\
\hline
\end{tabular}

Source: Office for National Statistics 


\section{Human capital stock overtime}

Figure 1 shows the annual estimates of the human capital stock for each of the years from 2001 to 2009. The estimates are inflated to 2009 prices using the consumer price index. The figures are calculated as annual averages to remove seasonal effects in the estimates and because there are three quarters of micro-data where no pay variable is available. ${ }^{15}$ The figure illustrates that the annual average human capital stock in the UK, measured in 2009 prices, increased by $£ 2,703$ billion from $£ 13,982$ billion in 2001 to $£ 16,686$ billion in 2009 . Figure 1 also illustrates the impact of the recession on the human capital stock. Between 2001 and 2007, the human capital stock grew by $£ 2,474$ billion in real terms, an average of $£ 412$ billion per year. In contrast, between 2007 and 2009 , the human capital stock grew by $£ 228$ billion. As illustrated in Figure 2, the human capital stock per head of working age population, measured in 2009 prices, increased from $£ 372,529$ in 2001 to 419,326 in 2009 with $£ 46,080$ of the $£ 46,797$ increase occurring between 2001 and 2007.

\section{Figure 1 Human capital stock, 2001-2009}

United Kingdom

$£$ Thousands

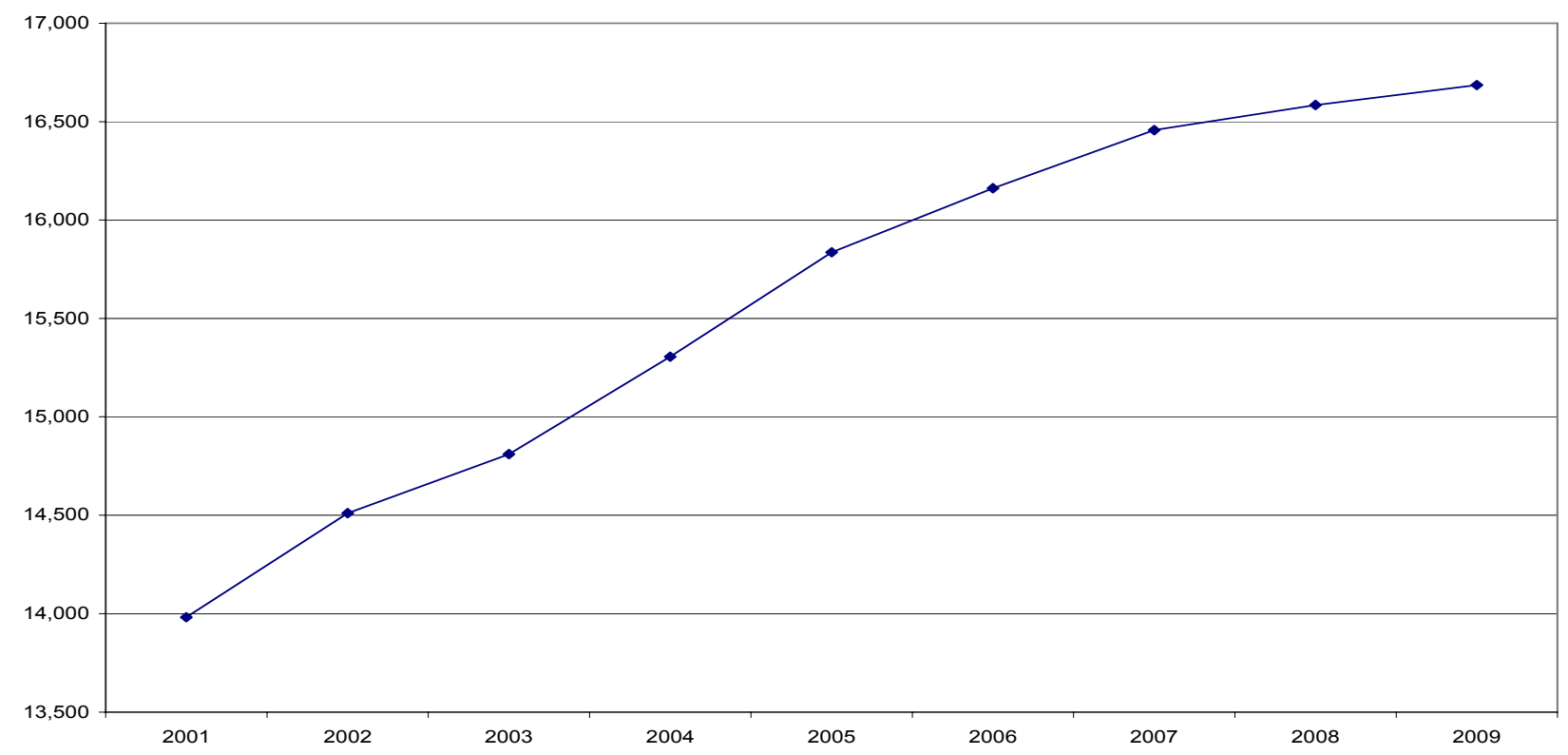

Source: Labour Force Survey

The increase in the human capital stock between 2001 and 2009 has been driven by several factors. First, the size of the working-age population increased from 37.5 million in 2001 to 39.9 million in 2009. Similarly, the number of people in employment increased from 27.3 million in 2001 to 28.2 million in 2009. To give an indication of the effect this had on the human capital stock, the estimate of the human capital in 2001 ( $£ 13,982$ billion) can be multiplied by the ratio of the number of people in employment in 2009 and 2001 to give $£ 14,506$ billion. Thus, holding other things 
equal, around $£ 524$ billion of the $£ 2,703$ billion increase in human capital between 2001 and 2009 can be attributed to the increase in the number of people employed over the same period. ${ }^{16}$ Between 2001 and 2009, mortality rates for working age individuals also fell. Again holding other things constant, using the mortality rates for 2009 instead of the 2001 rates, increases the estimate of the human capital stock in 2001 by $£ 49$ billion to $£ 14,031$ billion.

\section{Figure 2 Human capital per head of working age population, 2001- 2009}

United Kingdom

$£$ Thousands

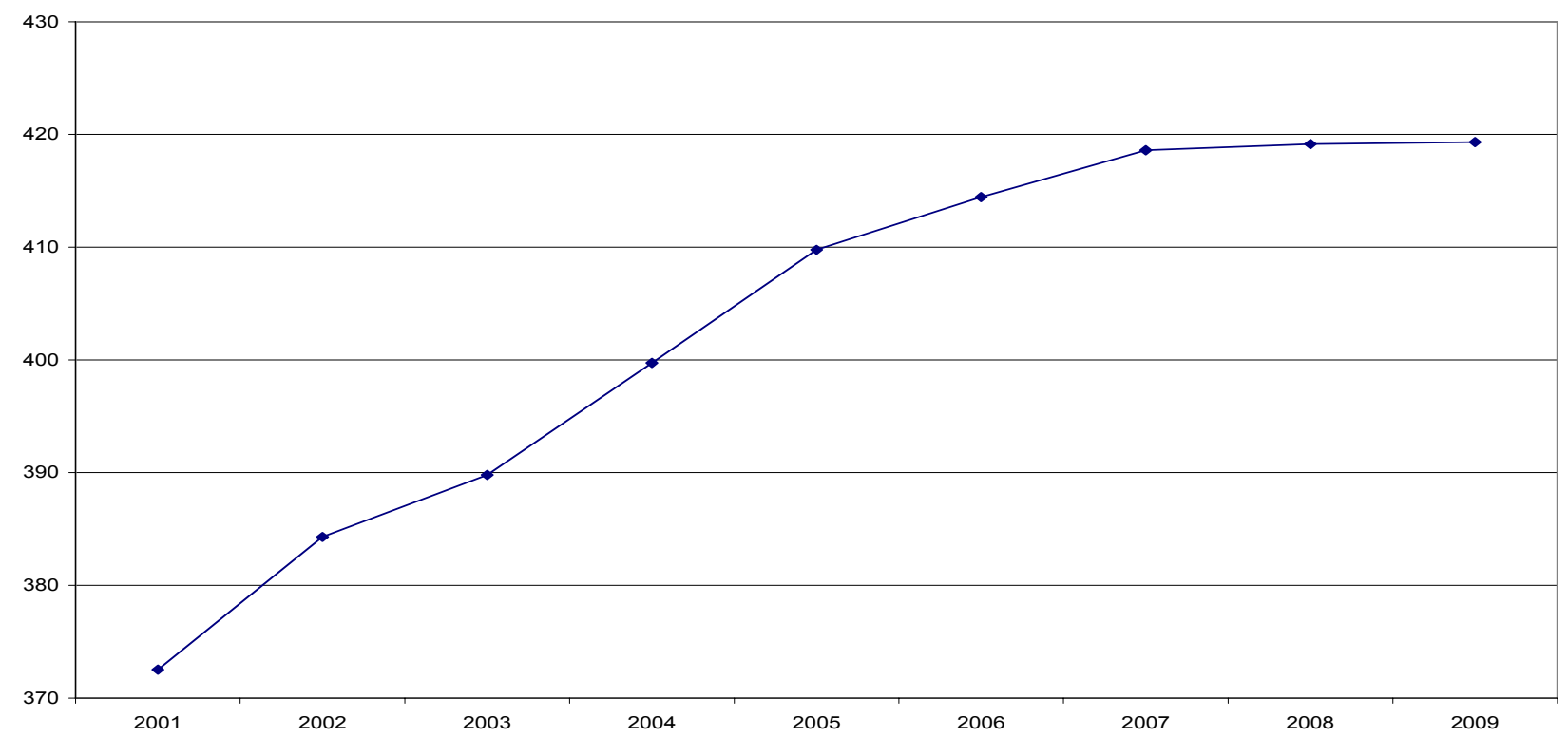

Source: Labour Force Survey

Figure 3 illustrates that between 2001 and 2009, the proportion of the working age population whose highest educational attainment is a degree or equivalent increased from 15.4 per cent (5.8 million people) in 2001 to 21 per cent ( 8.3 million people) in 2009 . Moreover, the proportion of the population with no qualifications fell from 16.4 per cent (6.1 million people) in 2001 to 12.2 per cent (4.8 million people) in 2009. Other things being equal, this would have been expected to increase the human capital stock since, as illustrated in Figure 4, individuals with degrees tend to earn more than the rest of the population. Applying the distribution of qualifications in 2009 to the 2001 working age population and holding everything else constant, the estimate of the human capital stock for 2001 increases to $£ 14,851$ billion so around $£ 869$ billion of the $£ 2,703$ billion increase in human capital between 2001 and 2009 can be attributed to changes in the qualifications mix of the working age population over the same period. 


\section{Figure 3 Distribution of highest educational qualification in the working age population, 2001-2009}

United Kingdom

Millions of people

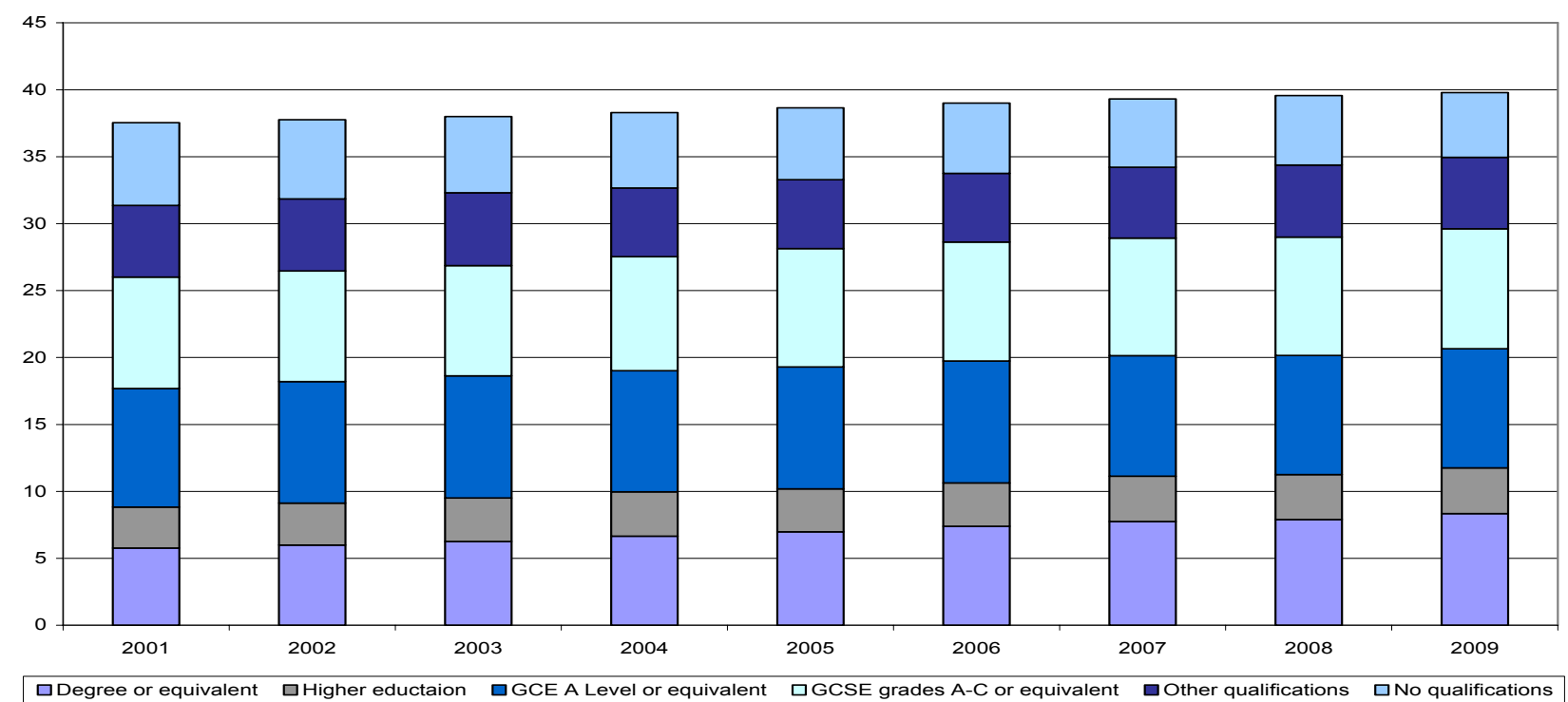

Source: Labour Force Survey

Figure 4 Median total annual income by highest educational attainment, 2001-2009

United Kingdom

$£$ Thousands

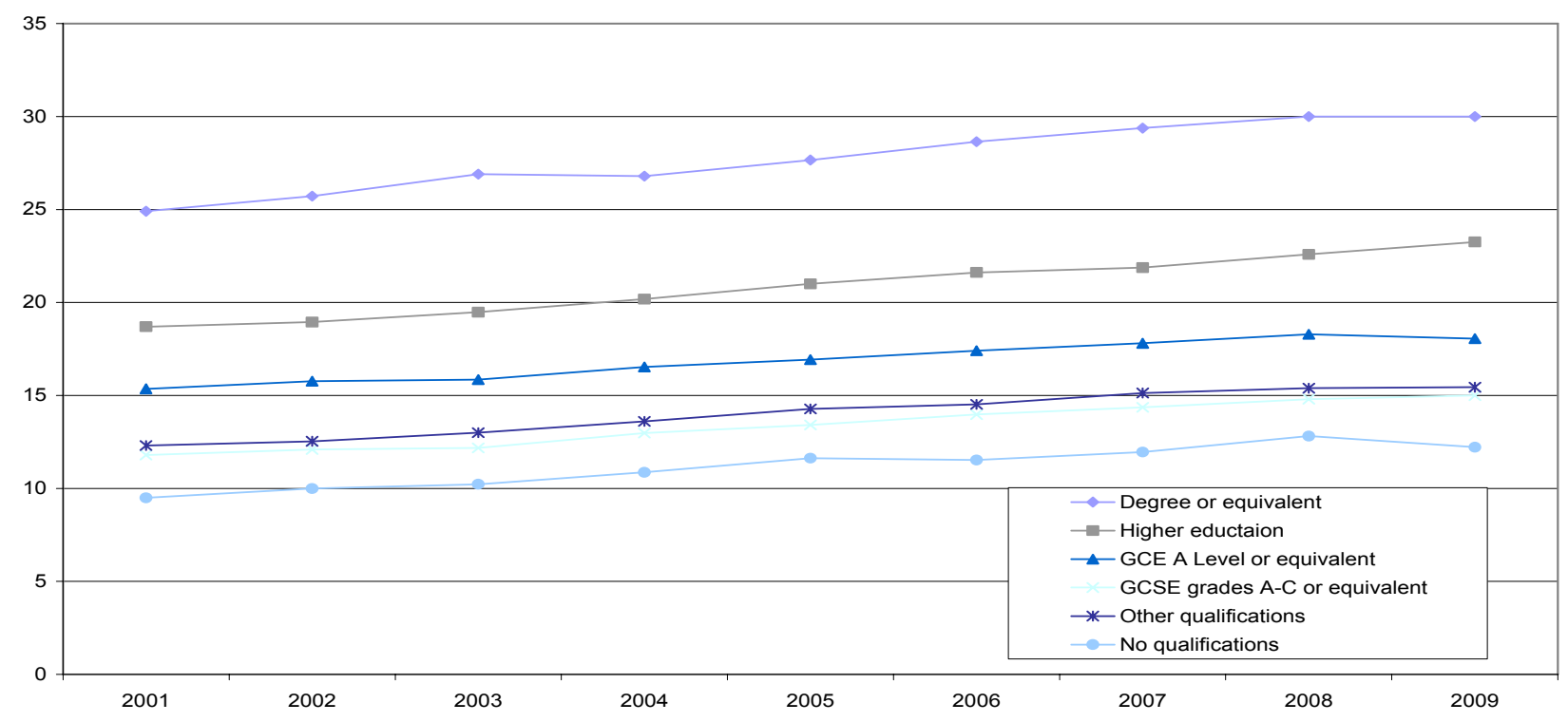

Source: Labour Force Survey 
Another important driver of this series is the changes in the earnings. Figure 4 illustrates that median total earnings grew in real terms for educational attainment groups and the absolute size of the increase was generally higher the higher the educational attainment, the exception being the earnings of those whose highest educational attainment was ' $A$ ' level or equivalent. For example, the median total earnings of those whose highest educational attainment is a degree or equivalent increased the most, by $£ 5,046$, between 2001 and 2009, whilst the median total income of those with no qualifications grew by $£ 2,721$. However, in proportionate terms, the ordering of the size of increase is reversed so that those with no qualifications had the highest proportional growth in their real total incomes.

Applying the earnings distribution in place in 2009 to the 2001 workforce, increases the estimate of the human capital stock in 2001 by $£ 998$ billion to $£ 14,980$ billion. This is decomposed by qualification in Table 4 and shows that almost two-thirds of the $£ 998$ billion increase came from the higher earnings of those whose educational attainment is a degree or equivalent and those whose highest educational attainment is GCSE grades $\mathrm{A}-\mathrm{C}$ or equivalent.

\section{Table 4 Contributions to human capital growth, 2001-2009}

\begin{tabular}{lc}
\hline Increases in the total earnings of those whose highest educational attainment is: & $£$ billion \\
\hline Degree or equivalent & 291 \\
Higher education & 61 \\
GCE A Level or equivalent & 99 \\
GCSE grades A-C or equivalent & 355 \\
Other qualifications & 102 \\
No qualifications & 89 \\
Total & 998 \\
\hline
\end{tabular}

Source: Office for National Statistics

\section{Conclusions}

\section{Main findings}

This paper has discussed the importance of human capital and how an economy's human capital stock can be measured. Using a discounted a lifetime labour income approach and assuming a discount rate of 3.5 per cent and labour productivity growth rate of 2 per cent, the UK's human capital stock was worth $£ 16,686$ billion in 2009. This is more than two-and-a-half times the Blue Book estimate of the Net Worth of the UK in the same year. ${ }^{17}$ The average human capital stock per head of working age population was $£ 419,326$ in the final quarter of 2009 . Less time in paid employment over their lifetime and lower average labour market earnings means that the market value of women's human capital ( $£ 6,481$ billion) is around sixty per cent of men's ( $£ 10,206$ billion). The paper also shows that the annual average human capital stock in the UK, measured in 2009 
prices, increased by $£ 2,663$ billion from $£ 13,982$ billion in 2001 . Human capital per head of working age population, again in 2009 prices and calculated as an annual average, increased from $£ 372,529$ to $£ 419,326$ over the same period.

\section{Applications}

This measure of human capital has several potential policy applications. First, it can be used as a measure of an economy's future well-being as the empirical work on economic growth suggests that countries with higher levels of human capital, other things being equal, have greater potential output and income in the future. The measures can also be used in the assessment of the impact of an ageing population, changes in retirement ages and in the evaluation of the economic benefits of different levels of education.

\section{Limitations}

As acknowledged in the section on methodology, this approach has some weaknesses. First, it relies on the assumption that labour is paid according to its marginal productivity. In practice, a range of institutional factors affect earnings. These measures are also sensitive to the choice of the discount rate and the retirement age. This method relies upon the use of current age-earnings profiles to project future earnings flows. The approach assumes that the attainment of educational qualifications is the main driver of higher earnings. Non-educational factors such as ability and family background are not taken into account. Thus, the estimated effect on lifetime labour incomes of educational attainments is likely to be over-estimated.

\section{Further work}

Non-wage benefits could be incorporated into the returns to qualifications. This is an important consideration when interpreting the relative valuation of human capital for women and men reported in Table 3. These experimental estimates of human capital are calculated using market factors only. Human capital is also important for non-market activity. Thus, one cannot conclude that male human capital is more 'valuable' to society than female human capital. Future work could incorporate imputations of the value of non-market labour activity, including household production and leisure into the measures of human capital.

The discounted lifetime income framework only considers formal education in its estimates of investment in human capital that enhances individuals' skills and knowledge, with the component of on-the-job training being mixed with its estimation of human capital. The standard human capital theory also emphasises the role of on-the-job training in human capital formation. This could be combined with the stock estimates to produce a capital accumulation account. 


\section{Acknowledgements}

The authors would like to Paul Allin, Joe Grice, Stephen Hicks, Donna Livesey, Craig Mclaren, participants at the 2010 Government Economic Service Conference, the 2010 International Association for Research in Income and Wealth (IARIW) Conference and a BIS/ONS workshop for their comments and suggestions.

\section{Notes}

1. The first attempt at valuing human capital was made by William Petty in 1690 (Petty, 1690), who estimated the total human capital of England to be $£ 520$ million or $£ 80$ per capita.

2. Other members of the consortium are 14 other OECD countries (Australia, Canada, Denmark, France, Italy, Japan, Korea, Mexico, Netherlands, New Zealand, Norway, Poland, Spain, and the United States), two accession countries (Israel and Russia) and one non-member country (Romania). Eurostat and the ILO are also members of the consortium. The consortium is assisted and coordinated by the OECD Secretariat.

3. It may be that as countries become richer they are able to devote more resources to education and training and so on.

4. The presence of positive externalities is one of the justifications for government subsidies to education and training. From society's point of view, individuals might under-invest in certain kinds of education since they do not take into account the wider benefits to society of their decision.

5. In his model, workers and firms are complementary in the production process. This means that additions to human capital that raise productivity also increase the rate of return on investments in physical capital. Thus, increases in the average level of human capital can lead firms to make greater investments in physical capital. Since the matching process is inefficient, the firms that have invested more in physical capital are not necessarily matched with the workers who have invested more in human capital. As a result, some of the other workers will gain from the increase in average human capital, since they are matched with firms using more physical capital than before.

6. Hulten (1990) and others have called this, 'one of the most difficult tasks in economics'.

7. There is a similar debate amongst financial accountants over the accounting treatment of human resources in company accounts for example Gall (1988) and Flamholtz et al (2002).

8. Further information on the Labour Force Survey can be found at www.statistics.gov.uk/statbase/Source.asp?vlnk=358

9. The data has population weights that allow results for population to be derived from the sample.

10. The retirement age for women is 60 years. However, we take 64 years as the general

retirement age given recent changes to the regulations.

11. Including 'Don't know'. The variable name in Q4 of 2009 is hiqual8.

12. Including 'Don't know'. The variable name in Q4 of 2009 is hiqual8d.

13. Assuming a uniform distribution of workers, the average working life remaining is $((65-16) / 2)$ $=24.5$.

14. A discount rate greater than a labour productivity growth rate and a shorter expected working life for women brings this closer to the $£ 16,686$ calculated.

15. In these years, the annual figure is calculated as the average of the three remaining quarters. 
16. Although the implicit assumption made in this calculation is that, on average, the human capital of additional individuals is identical to that of existing workers and that the additional individuals have no impact on the human capital of existing individuals.

17. United Kingdom National Accounts: The Blue Book 2010, Table 10.1.

\section{Contact}

elmr@ons.gov.uk

\section{References}

Acemoglu D (1996) 'Credit constraints, investment externalities and growth'. In Booth A and Snower D (eds.) Acquiring Skills. Cambridge University Press, 41-62.

Appelbaum S H and Hood J (1993) Accounting for the firm's human resources. Managerial Auditing Journal, 8(2) 17-24.

Atkinson T (2005) 'Atkinson Review: Final Report - Measurement of Government Output and Productivity for the National Accounts'. TSO, London, January.

Azariadis C and Drazen A (1990) Threshold externalities in economic development. Quarterly Journal of Economics, 105(2), 501-526.

Barro R J (1991) Economic growth in a cross section of countries. Quarterly Journal of Economics, 106(2), 407-443.

Barro R J and Lee J-W (1993) International comparisons of educational attainment. Journal of Monetary Economics, 32 (3), 363-394.

Barro R J and Lee J-W. (1996) International measures of schooling years and schooling quality. American Economic Review, 86 (2), 218-223.

Barro R J and Sala-i-Martin X (2004). Economic growth (2 ${ }^{\text {nd }}$ Edition). Boston: MIT Press.

Bartel A P and Lichtenberg F R (1987) The Comparative Advantage of Educated Workers in Implementing New Technology. The Review of Economics and Statistics, MIT Press, vol. 69(1), pages 1-11, February.

Becker G S (1975) Human Capital, $2^{\text {nd }}$ Edition. Chicago: Chicago University Press.

Behrman J R and Birdsall N (1983) The quality of schooling: quantity alone is misleading. American Economic Review, 73(5), 928-946.

Behrman J R and Stacey N (1997) The social benefits of education. Ann Arbor: University of Michigan Press. 
Berman E, Bound J and Machin S (1998) Implications Of Skill-Biased Technological Change: International Evidence The Quarterly Journal of Economics, 113(4), 1245-1279.

Bowman M J, (1962). Economic of Education, HEW Bulletin, 5.

Card D (1999) 'The causal effects of schooling on earnings'. In O. Ashenfelter and D. Card (eds.) Handbook of Labor Economics. Amsterdam: North Holland.

CMEPSP (2009) Report of the commission on the measurement of economic performance and social progress. OECD, Paris.

Denison E F (1962) 'The Sources of Economic Growth in the United States and the Alternatives before us'. Committee for Economic Development, Supplementary Paper No. 13, New York.

Doeringer P and Piore M (1971) Internal Labor Markets and Manpower Analysis. DC Heath, Lexington, Ma.

Durlauf S N, Johnson P A and Temple J R W (2005) 'Growth econometrics'. In P Aghion and S N Durlauf (eds.) Handbook of Economic Growth, Volume 1A Amsterdam: North-Holland, 555-677.

Eurostat (1995) European System of Accounts-ESA 95, Luxembourg, Eurostat.

Eisner R (1985) Extended accounts for national income and product. Journal of Economic Literature, 26(4):1611-1684.

Eisner R (1989). The Total Incomes System of Accounts. Chicago: University of Chicago Press, I.L.

Farr W (1853) Equitable taxation of property. Journal of Royal Statistics, 16, 1-45.

Francesconi M, Jenkins S P and Siedler T (2005) 'Childhood Family Structure and Schooling Outcomes: Evidence for Germany'. IZA Discussion Papers 1837, Institute for the Study of Labor (IZA) (Revised).

Gang I N and Zimmermann K F (2000) Is Child like Parent? Educational Attainment and Ethnic Origin. The Journal of Human Resources, 35(3), 550-569.

Gemmell N (1996) Evaluating the impacts of human capital stocks and accumulation on economic growth: some new evidence. Oxford Bulletin of Economics and Statistics, 58(1), 9-28.

Graham J W and Webb R H (1979) Stocks and depreciation of human capital: new evidence from a present-value perspective. Review of Income and Wealth, 25(2), 209-224.

Greenwood D T (1997) New Developments in the Intergenerational Impacts of Education. International Journal of Education Research, 27(6), 503-512.

Grip A and van Loo J (2002) 'The Economics of Skills Obsolescence: A Review'. In de Grip A van Loo J and Mayhew K (eds.) The Economics of Skills Obsolescence. Research in Labor Economics, 21, 1-26. 
Grogger J (1998) Market Wages and Youth Crime. Journal of Labor Economics 16(4), 756-791.

Grossman, M and Kaestner R (1996) 'Effects of Education on Health'. In Behrman J R and Stacey N (eds.) The Social Benefits of Education. Philadelphia: University of Pennsylvania.

Gu W and A Wong (2008) Human development and its contribution to the wealth accounts in Canada, paper presented at the OECD workshop on 'The Measurement of Human Capital' in Turin, Italy, 3-4, November, 2008.

Hanushek E A (1971) Teacher Characteristics and Gains in Student Achievement: Estimation Using Micro Data. American Economic Review, 61(2), 280-88.

Hanushek E A, and Dongwook K (1995), Schooling, labor force quality, and economic growth. Working Paper 5399, National Bureau of Economic Research (December).

Haveman R and Wolfe B (1984) Schooling and economic well-being: the role of non-markets effects. Journal of Human Resources, 19(3), 377-407.

Helliwell J F and Putnam R D (1999) 'Education and Social Capital'. NBER Working Paper 7121.

HM Treasury (2003) The Green Book: Appraisal and Evaluation in Central Government. HMSO

Hulten C (1990) 'The Measurement of Capital, In Fifty Years of Economic Measurement'. In Berndt and Triplett (eds), Studies in Income and Wealth, 54, National Bureau of Economic Research.

Jorgenson D W and B M Fraumeni (1992a) 'The Output of Education Sector'. In: Z Griliches (ed.) Output Measurement in the Service Sectors, The University of Chicago Press, Chicago.

Jorgenson D W and B M Fraumeni (1992b), Investment in Education and U.S. Economic Growth, Scandinavian Journal of Economics, 94, Supplement, 51-70.

Jorgenson D W and B M Fraumeni (1989), The Accumulation of Human and Non-Human Capital, 1948-1984, In The Measurement of Savings, Investment, and Wealth, ed. R E Lipsey and H S Tice, 227-82. The University of Chicago Press, Chicago.

Jorgenson D W and Griliches A (1967) The Explanation of Productivity Change. Review of Economic Studies, 34, 349-83.

Jovanovic B and Rob R (1989) The Growth and Diffusion of Knowledge. Review of Economic Studies 56, 569-582.

Judson R (2002) Measuring human capital like physical capital: what does it tell us? Bulletin of Economic Research, 54(3), 209-231.

Kendrick J W (1976) The Formation and Stock of Total Capital. New York: Columbia University Press.

Kyriacou G (1991) Level and growth effects of human capital: a cross country study of the convergence hypothesis. Economic Research Reports 91-26, New York University. 
Lau L J, Jamison D T and Louat F (1991) 'Education and productivity in developing countries: an aggregate production function approach'. Policy Research Working Paper Series 612, The World Bank.

Lavy V (2002) Evaluating the Effect of Teacher Performance Incentives on Students' Achievements. Journal of Political Economy, 10(6), 1286-1318.

Le T, Gibson J and Oxley L (2006): A Forward-Looking Measure of the Stock of Human Capital in New Zealand, The Manchester School, Vol.74, No.5, 593-609.

Levine R E and Renelt D (1992) A sensitivity analysis of cross-country growth regressions. American Economic Review, 82(4), 942-963.

Lindsay C (2004), Labour Productivity, Office for National Statistics. Labour Market Trends, November 2004.

Liu G and Greaker M (2009), Measuring the stock of human capital for Norway - A lifetime labour income approach, Documents, 2009/12, Statistics Norway.

Lochner L and Moretti E (2004) The Effect of Education on Crime: Evidence from Prison Inmates, Arrests, and Self-Reports, American Economic Review, 94(1): 155-189.

Lucas R E (1988) On the mechanics of economic development. Journal of Monetary Economics 22, 3-42.

Machlup F (1984) The Economics of Information and Human Capital, Volume 3. Princeton: Princeton University Press, N.J.

Mankiw N G, Romer D and Weil D N (1992) A contribution to the empirics of economic growth. Quarterly Journal of Economics, 107(2), 407- 437.

Maynard R A and McGrath D J (1997) 'Family Structure, Fertility and Child Welfare'. In: Behrman J and Stacey N (eds.) The Social Benefits of Education. Ann Arbor: University of Michigan Press.

Milligan K, Moretti E and Oreopoulos P.(2003) Does education improve citizenship? Evidence from the US and the UK, NBER working paper 9584.

Mincer J and Polachek S (1974). Family investment in human capital: earnings of women. Journal of Political Economy 82(2), Pt II, March-April, S76-S108.

Organization for Economic Cooperation and Development (OECD). (1996) Measuring What People Know: Human Capital Accounting for the Knowledge Economy. OECD, Paris.

Organization for Economic Cooperation and Development (OECD). (2001a) The wellbeing of nations: the role of human and social capital. OECD, Paris.

Organization for Economic Cooperation and Development (OECD). (2001b) ' Measuring Capital: OECD Manual Measurement of Capital Stocks, Consumption of Fixed Capital and Capital Services' OECD, Paris. 
Petty W (1690). 'Political Arithmetik'. Reprinted in: C H Hull (1899), The Economic Writings of Sir William Petty. Cambridge: Cambridge University Press.

Psacharopoulos G (1994) Returns to investment in education: a global update. World Development, 22(9), 1325-1343.

Psacharopoulos G and Arriagada A M (1986) The educational composition of the labour force: an international comparison. International Labour Review, 125(5), 561-574.

Psacharopoulos G and Arriagada A M (1992) The educational composition of the labour force: an international update. Journal of Educational Planning and Administration, 6(2), 141-159.

Psacharopoulos G and Patrinos H A (2004) Returns to Investment in education: A further update. Education Economics 12(2), 111-134.

Romer P M (1989a) Human capital and growth: theory and evidence. Working Paper 3173, National Bureau of Economic Research, Cambridge, M.A.

Romer P M (1989b) Capital accumulation in the theory of long-run growth. In Robert J Barro (ed.) Modern business cycle theory. Oxford: Basil Blackwell.

Romer P M (1994) The origins of endogenous growth. Journal of Economic Perspectives, Winter, 8, 3-22.

Rosen S (1985) The theory of equalizing differences. In Handbook of Labour Economics, ed. O Ashenfelter and R Layard. Amsterdam: North-Holland.

Schuller T, Bynner J, Green A, Blackwell L, Hammond C and Preston J (2001) 'Modelling and Measuring the Wider Benefits of Learning: A Synthesis'. Wider Benefits of Learning Papers No. 1. London: Institute of Education.

Schultz T W (1960) Capital Formation by Education. Journal of Political Economy, 68, 571-583.

Schultz T W (1969) 'Investment in Human Capital'. In: Phelps E S (ed.) The Goal of Economic Growth. New York: Norton.

Schultz, T. W. (1971) Investment in Human Capital. New York. The Free Press.

Shaffer H G (1961) Investment in human capital: comment. American Economic Review, 51(5), 1026-1034.

Sloane P (2003) Much ado about nothing? What does the overeducation literature really tell us. In Buchel, de Grip and Mertens (eds), Overeducation in Europe (pp. 11-49). Cheltenham: Edward Elgar.

Solow R M (1988) ‘Growth Theory and After.' American Economic Review 78, 307-317.

Spence M (1973) Job Market Signalling. Quarterly Journal of Economics, 87(3), 355-374. 
Wachtel P (1997) A labor-income based measure of the value of human capital: an application to the states of the US: comments. Japan and the World Economy, 9(2), 193-196.

Wei H (2004), Measuring the Stock of Human Capital for Australia, Working Paper No. 2004/1, Australian Bureau of Statistics.

Wei H (2007), Measuring Australia's Human Capital Development: The Role of Post-School Education and the Impact of Population Ageing, Statistical Journal of the IAOS 24, 183-191.

Weiss A (1996) Human Capital vs Signalling Explanations of Wages. Journal of Economic Perspectives, 9(4), 133-54.

Wolff E N (2000) Human capital investment and economic growth: exploring the cross-country evidence. Structural Change and Economic Dynamics, 11(4), 433-472. 